\title{
EFEKTIFITAS METODE LOTUS BIRTH TERHADAP KEJADIAN ANEMIA DEFISIENSI ZAT BESI PADA BAYI
}

\author{
Parida Hanum ${ }^{1}$, Sri Wahyuni Nasution ${ }^{2}$ \\ 1,2Universitas Prima Indonesia Medan \\ Email: paridahanum@unprimd.ac.id ${ }^{1}$, sriwahyuni_nst88@yahoo.com ${ }^{2}$
}

\begin{abstract}
The controversy over the Lotus Birth method for general application is still being debated, but the consensus to delay cord clamping and cutting has been agreed and agreed by WHO that the umbilical cord is clamped after stopping to beat to allow increased blood flow to the baby to prevent anemia. The objective of the research was to find effectiveness of the lotus birth method for the incidence of anemia in infants. The research is done by using quasy experiment with sample infants born spontaneously, having 38-40 weeks of pregnancy and without complications using the lotus birth method (15 people) and the control group not using the lotus birth method (15 people). Analysis method of data uses independent t-test. The result of the research showed no Effectiveness of the lotus birth method for the incidence of iron deficiency anemia in infants at the Klinik Pratama Sejahtera $(p=0,865)$.The conclusion in this study isno Effectiveness of the lotus birth method for the incidence of iron deficiency anemia in infants at the Klinik Pratama Sejahtera. It is expected that pregnant women should prepare themselves in the face of childbirth by increasing knowledge about how to maintain health and care for babies to avoid the occurrence of iron deficiency anemia.
\end{abstract}

Keywords: lotus birth, anemia, deficiency, iron, infants

\section{PENDAHULUAN}

Anemia defisiensi besi pada bayi merupakan masalah kesehatan yang dapat terjadi yang hampir terdapat di seluruh negara berkembang. Lebih dari $50 \%$ di negara berkembang diperkirakan mengalami anemia pada tahun pertama kehidupannya. Anemia defesiensi besi merupakan kejadian yang sering terjadi pada bayi dengan kejadian tertinggi pada umur 6- 24 bulan (IDAI, 2013).

Pemotongan tali pusat biasanya dilakukan setelah bayi lahir, dan pada saat plasenta masih ada di dalam tubuh ibu. Pada lotus birth, tali pusat bayi tidak dipotong sehingga tetap menempel pada plasenta atau ari-ari. Proses pemisahan antara tali pusat dan plasenta ditunggu secara alami setelah beberapa hari kemudian (Khan, De Wall, Craven, 2012).

Metode lotus birth adalah metode persalinan yang tali pusat dibiarkan tetap terhubung dengan bayi dan plasenta setelah kelahiran, tanpa menjepit ataupun memotongnya, sehingga kuman tidak memiliki peluang untuk masuk ke dalam tubuh bayi melalui tali pusat. 
Metode lotus birth ini diyakini dapat menambah kekebalan tubuh bayi yang baru lahir. Dengan metode ini, bayi diharapkan mendapatkan lebih banyak asupan darah yang mengandung oksigen, makanandan anti bodi sehingga memberikan waktu bagi tali pusat untuk terpisah dari bayi secara alamiah. Dengan metode ini pula, tali pusat dan plasenta diperlakukan sebagai suatu kesatuan sampai saat pemutusan secara alami yang biasanya terjadi 3-10 hari setelah proses persalinan (Herlyssa, Mulyati, \& Martini, 2015).

Lotus birth hingga kini belum memiliki bukti ilmiah yang diakui secara medis. Walaupun dalam beberapa penelitian menemukan bahwa terdapat manfaat menunda pemotongan tali pusat selama beberapa saat. Yang perlu ditekankan, hal ini berbeda dengan praktik lotus birth yang membiarkan tali pusat berhari-hari hingga putus secara alami. Berdasarkan beberapa pengujian pada bayi lahir tepat waktu dan bayi prematur, terdapat beberapa manfaat yang dapat diperoleh dari penundaan pemotongan tali pusat. Bayi baru lahir akan menerima pasokan darah dari plasenta yang masih terhubung. Pasokan darah tambahan terhitung sekitar 30\% lebih banyak, jika dibandingkan dengan bayi yang tali pusatnya langsung dipotong (Alodokter, 2018).

Secara medis, penundaan pemotongan tali pusat selama 3 jam saja dapat dipercaya memberikan asupan darah sebanyak 30 mililiter dari plasenta, yang nutrisinya sebanding dengan 60 mililiter darah orang dewasa. Selain itu sistem imun bayi mengalami tantangan saat baru dilahirkan. Membiarkan tali pusat lepas secara alamiah akan menjaga volume darah bayi dan membantu si bayi terhindar dari beberapa penyakit dimasa yang akan datang. Secara kepercayaan holistik diyakini bahwa bayi memiliki ikatan erat dengan plasenta yang telah menemaninya selama sembilan bulan didalam rahim (Roesma dan Mulya, 2014).

Lotus Birth jarang dilakukan di rumah sakit tetapi umumnya dilakukan di klinik dan rumah bersalin. Di Indonesia metode persalinan lotus birth sampai saat ini sudah banyak dilakukan di Bali. Lotus birth memungkinkan terjadinya proses bonding attachment antara ibu dan bayi, hal ini tentunya bermanfaat bagi ibu dan bayi yang baru lahir. Menurut Organisasi Kesehatan Dunia (WHO) menekankan pentingnya penyatuan atau penggabungan pendekatan untuk asuhan ibu dan bayi, 
dan menyatakan dengan jelas bahwa menunda pengkleman (atau tidak sama sekali diklem) adalah cara fisiologis dalam perawatan tali pusat, dan pengkleman tali pusat secara dini merupakan intervensi yang masih memerlukan pembuktian lebih lanjut (Aprilia, 2019).

Rumusan masalah dalam penelitian ini adalah apakah metode lotus birth efektif dalam mencegah kejadian anemia defisiensi zat besi pada bayi?. Tujuan yang ingin dicapai dalam penelitian yaitu mengidentifikasi dan menganalisis efektifitas metode lotus birth terhadap kejadian anemia pada bayi.

\section{METODE PENELITIAN}

Penelitian ini menggunakan metode penelitian Quasi Eksperiment yang bertujuan untuk mengetahui efektifitas metode lotus birth terhadap kejadian anemia di Klinik Pratama Sejahtera. Penelitian ini dilaksanakan di Klinik Pratama Sejahtera dengan sampel sebanyak 30 orang bayi yang terdiri dari kelompok kasus (yang menggunakan metode lotus birth) sebanyak 15 orang dan kelompok kontrol (yang tidak menggunakan metode lotus birth) sebanyak 15 orang. Teknik pengumpulan data dilakukan dengan menggunakan wawancara, observasi yang mengacu pada kerangka konsep dan tinjauan pustaka. Teknik analisa yang digunakan yaitu analisa univariat dan analisa bivariat yang bertujuan untuk melihat perbedaan kadar haemoglobin berdasarkan tindakan dilakukan lotus birth dengan tidak dilakukan lotus birth pada bayi baru lahir dengan persalinan normal dengan uji tindependen.

\section{HASIL}

Tabel 1 Distribusi Kadar Hb pada Bayi yang Menggunakan Lotus Birth $(\mathrm{n}=15)$

\begin{tabular}{ccc}
\multicolumn{3}{c}{$(\mathrm{n}=15)$} \\
\hline No & Kadar HB $(\mathrm{gr} / \mathrm{dl})$ & Kategori \\
\hline 1 & 16 & Anemia \\
2 & 15 & Anemia \\
3 & 16 & Anemia \\
4 & 18 & Tidak Anemia \\
5 & 19 & Tidak Anemia \\
6 & 17 & Tidak Anemia \\
7 & 20 & Tidak Anemia \\
8 & 18 & Tidak Anemia \\
9 & 15 & Anemia \\
10 & 20 & Tidak Anemia \\
11 & 17 & Tidak Anemia \\
12 & 18 & Tidak Anemia \\
13 & 13 & Anemia \\
14 & 15 & Anemia \\
15 & 19 & Tidak Anemia \\
\hline
\end{tabular}

Berdasarkan tabel 1 di atas dapat lihat bahwa mayoritas responden yang menggunakan metode lotus birth tidak mengalami anemia defisiensi zat besi. 
Tabel 2 Distribusi Kadar Hb pada Bayi yang Menggunakan Lotus Birth $(n=15)$

\begin{tabular}{ccc}
\hline No & $\begin{array}{c}\text { Kadar HB } \\
(\text { gr/dl })\end{array}$ & Kategori \\
\hline 1 & 19 & Tidak Anemia \\
2 & 19 & Tidak Anemia \\
3 & 15 & Anemia \\
4 & 19 & Tidak Anemia \\
5 & 20 & Tidak Anemia \\
6 & 19 & Tidak Anemia \\
7 & 19 & Tidak Anemia \\
8 & 18 & Tidak Anemia \\
9 & 14 & Anemia \\
10 & 16 & Anemia \\
11 & 18 & Tidak Anemia \\
12 & 16 & Anemia \\
13 & 19 & Tidak Anemia \\
14 & 15 & Anemia \\
15 & 20 & Tidak Anemia \\
\hline
\end{tabular}

Berdasarkan tabel 2 di atas dapat lihat bahwa mayoritas responden yang tidak menggunakan metode lotus birth juga btidak mengalami anemia defisiensi zat besi.

Tabel 3 Uji Normalitas Data

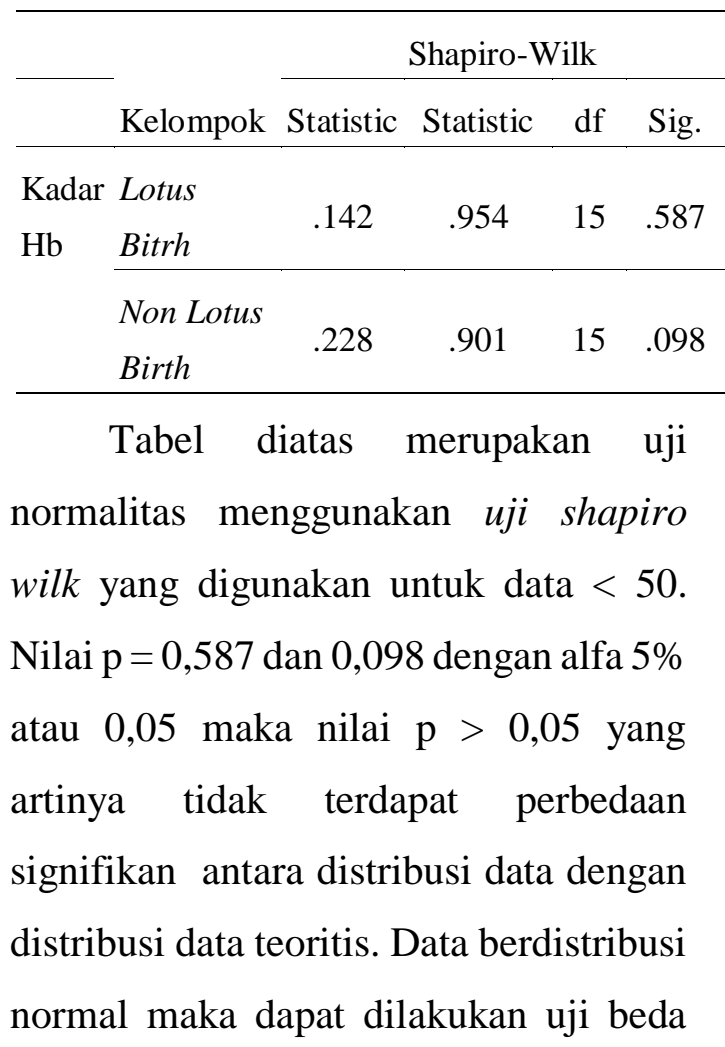

secara parametrik dengan uji $t$ independent.

Tabel 4 Efektivitas Metode Lotus Birth Terhadap Kejadian Anemia Defisiensi Zat Besi Pada Bayi

\begin{tabular}{|c|c|c|c|c|c|}
\hline Variabel & Mean & SD & $\begin{array}{c}\text { Levene's } \\
\text { test }\end{array}$ & $\begin{array}{c}\mathrm{P} \\
\text { value }\end{array}$ & $\mathrm{n}$ \\
\hline $\begin{array}{c}\text { Metode } \\
\text { Lotus } \\
\text { Birth }\end{array}$ & 17,07 & 2,052 & 0,487 & 0,865 & 15 \\
\hline $\begin{array}{c}\text { Metode } \\
\text { Non } \\
\text { Lotus } \\
\text { Birth }\end{array}$ & 16,93 & 2,187 & & & 15 \\
\hline
\end{tabular}

Pada tabel 4 diatas diperoleh ratarata kadar $\mathrm{Hb}$ bayi yang menggunakan metode lotus birth dan metode non lotus birth adalah 17,07 dan 16,93 dengan standar deviasi 2,052 dan 2,187. Nilai Sig Leven'e test for equality of vairiances adalah 0,487 > 0,05 maka dapat diartikan bahwa varians data antara kadar $\mathrm{Hb}$ yang menggunakan metode lotus dan non lotus birth adalah homogen atau sama. Berdasarkan uji $t$ independen diperoleh nilai P-value 0,865. Maka dapat disimpulkan bahwa metode lotus birth tidak efektif terhadap kejadian anemia defisiensi zat besi pada bayi di Klinik Pratama Sejahtera.

\section{PEMBAHASAN}

Berdasarkan hasil penelitian diperoleh hasil bahwa metode lotus birth tidak efektif terhadap kejadian anemia defisiensi zat besi pada bayi di Klinik 
Pratama Sejahtera. Hasil ini tidak sesuai dengan penelitian Siswati dan Natiqotul(2013) yang memperoleh hasil bahwa tindakan lotus birth tidak efektif untuk mengurangi kejadian anemia defesiensi zat besi bayi baru lahir pada persalinan normal di BPM Kabupaten Tegal tahun 2013.

Manurut Cunningham (2016) lotus birth atau sering disebut dengan persalinan teratai adalah suatu metode persalinan dengan meninggalkan tali pusat yang belum dipotong sampai pemisahan terjadi secara alami. Kemudian tali pusat mengering dan akhirnya lepas dari umbilicus. Pelepasan tersebut umumnya terjadi 3-10 hari setelah lahir.

Hasil penelitian juga diperoleh bahwa rata-rata kadar HB bayi yang menggunakan metode lotus birth dan metode non lotus birth adalah 17,07 dan $16,93 \mathrm{gr} / \mathrm{dl}$. Berdasarkan penelitian Andriati (2012) memperoleh hasil bahwa salah satu manfaat lotus birth adalah memungkinkan terjadinya perpanjangan aliran darah ibu ke janin. Oksigen vital yang melalui tali pusat dapat sampai kepada bayi sebelum bayi benar-benar dapat mulai bernafas sendiri.
Hingga kini lotus birth belum memiliki bukti ilmiah yang diakui secara medis. Akan tetapi, terdapat beberapa penelitian memperoleh hasil bahwa kemungkinan manfaat penundaan pemotongan tali pusat selama beberapa saat. Akan tetapi, hal ini berbeda dengan praktik lotus birth yang membiarkan tali pusat berhari-hari hingga putus secara alami. Karena membiarkan jaringan plasenta mati penuh darah seperti pada lotus birth, dapat menjadi tempat berkembang biak bakteri yang berbahaya bagi bayi (Alodokter, 2018).

Melahirkan dengan metode lotus birth mulai diminati karena dianggap lebih alami dan membuat bayi memiliki kekebalan tubuh lebih tinggi. Namun secara ilmu kedokteran, metode ini masih dianggap kontroversi dan dapat berisiko untuk bayi. Pada persalinan normal, ketika bayi lahir maka tali pusat langsung diklem dan dipotong. Akan tetapi, pada persalinan metode lotus birth ini dipercaya dapat mencegah anemia dan membuat bayi memiliki kekebalan tubuh yang tinggi, karena dipercaya bahwa darah yang masih mengalir dari plasenta dapat memberikan tambahan oksigen, makanan dan antibodi untuk si bayi. Namun secara kedokteran, metode 
ini masih dianggap kontroversial dan belum ada penelitiannya secara ilmiah.

Metode lotus birth dianggap dapat menambah kekebalan tubuh dan mencegah anemia pada bayi baru lahir. Dengan metode ini, bayi diharapkan mendapatkan lebih banyak darah yang mengandung oksigen, makanan dan antibodi. Namun perlu ditegaskan bahwa plasenta bisa memproduksi antibodi hanya bila masih berada di dalam rahim ibu. Apabila sudah di berada di luar rahim ibu maka secara otomatis tidak dapat memproduksi antibodi lagi. Darah yang masih ada di plasenta hanyalah sisa-sisa yang jumlahnya tidak seberapa (Doktersehat, 2018).

Menurut asumsi peneliti bahwa kejadian anemia defisiensi pada bayi baru lahir dipengaruhi pada status kesehatan si ibu. Ibu hamil yang menderita anemia defisiensi besi meningkatkan risiko terjadinya pendarahan, preeklampsia, dan infeksi. Ibu hamil yang menderita anemia juga berisiko melahirkan bayi dengan berat lahir rendah, bayi dengan anemia ataupun kekurangan zat besi, bahkan kematian pada bayi.

\section{KESIMPULAN}

Metode lotus birth tidak efektif mencegah kejadian anemia defisiensi zat di Klinik Pratama Sejahtera, disebabkan bahwa anemi pada bayi dipengaruhi oleh status gizi ibu.

\section{UCAPAN TERIMA KASIH}

Terima kasih kepada Kementerian Riset, Teknologi dan Pendidikan Tinggi yang telah memberikan kesempatan kepada saya untuk mendapatkan hibah Penelitian Dosen Pemula (PDP) dan terima kasih kepada pihak LPPM Universitas Prima Indonesia yang selalu memberikan dukungan sehingga penelitian ini dapat diselesaikan dengan baik.

\section{SARAN}

Diharapkan kepada ibu hamil sebaiknya mempersiapkan diri dalam menghadapi persalinan dengan meningkatkan pengetahuan mengenai cara menjaga kesehatan dan merawat bayi agar tidak terjadi kejadian anemia defisiensi zat besi. Kejadian anemia pada bayi dapat dicegah dengan menjaga kesehatan, pola nutrisi ibu dan sibayi.

\section{DAFTAR PUSTAKA}

Khan, A., De Wall, K, \& Craven, P. (2012). Lotus birth: A red herring. Journal of Paediatrics and Child Health, 48, 111.

Alodokter. (2018, Juni 15). Fakta-fakta Tentang Lotus Birth. Retrieved from https://www.alodokter.com/faktafakta-tentang-lotus-birth 
Andriati, R. (2012). Manfaat lotus birth pada bayi baru lahir benefits of birth lotus in newborn. 1, No 1, 114.

Aprilia, Y. (2019). Lotus Birth Gentle Way To Gentle Birth \& Gentle Mothering. Retrieved from http://www.bidankita.com/lotusbirth-aeoea-gentle-way-to-gentlebirth-gentlemotheringae $\% c 2 \% 9 \mathrm{~d} / 2 /$

Cunningham, E. (2016). Is water birth natural for the fetus? MIDIRS Midwifery Digest, 26(2), 203-208.

Doktersehat. (2018). Amankah Melahirkan dengan Metode Lotus Birth?.

Retrieved fromhttps://doktersehat.com/aman kah-melahirkan-dengan-metodelotus-birth/

Herlyssa, H., Mulyati, S., \& Martini, R. (2015). Perbedaan Pertumbuhan Bayi Baru Lahir Pada Metode Lotus
Birth. Jurnal Ilmu Dan Teknologi Kesehatan, 2(2), 1-9.

IDAI. (2013, September 5). Anemia Defisiensi Besi Pada Bayi Dan Anak. Retrieved from http://www.idai.or.id/artikel/seputa r-kesehatan-anak/anemiadefisiensi-besi-pada-bayi-dan-anak

Roesma, J., \& Mulya, N. (2014). Moms and the city cerita seru mamud masa kini. Jakarta: PT Gramedia Pustaka Utama.

Siswati dan Natiqotul. (2013). Efektivitas lotus birth dengan kejadian anemia defesiensi zat besi bayi baru lahir pada persalinan normal di BPM Kabupaten Tegal tahun 2013. BHAMADA, JITK, 6(1), 173-182. 